\title{
The Comparative Analysis of the Styles of Christian Churches in Modern Mainland China, Macau and Hong Kong
}

\author{
Xinyu $\mathrm{Li}^{1,2}$, Jian Tang ${ }^{1,2^{*}}$ \\ ${ }^{1}$ Guangdong Engineering Technology Research Center for Green Building Materials and Fabricated Architecture, Maoming, China \\ ${ }^{2}$ Key Laboratory of Disaster Forecast and Control in Engineering (Jinan University), MOE of China
}

\begin{abstract}
Chinese Christian (Catholic) architecture is not only an important type of religious architecture, but also an important witness of cultural exchanges between China and the West. This article comprehensively summarizes the architectural styles of Christian (Catholic) churches in modern mainland China, Macau and Hong Kong, and compares the differences in the main styles of their churches horizontally. Based on the data results, a comprehensive analysis of various factors such as age, region, religion, and society is carried out to further explore the reasons for the differences in the architectural styles of Christian churches in the three regions, and discover the historical and religious significance of the Christian churches in modern China.
\end{abstract}

\section{Introduction}

Historically, Christianity (Catholicism) has been introduced to China three times, among which the third mission began in the 16th century (late Ming Dynasty), first in Shangchuan Island, Guangdong Province, and then into the mainland through Macau. Large-scale preaching was mainly after the Opium War in the middle of the 19th century, with the help of a series of unequal treaties to establish churches. Most of the existing churches in Mainland China, Macau and Hong Kong were brought by the third Christian (Catholic) entering China. Chinese Christian architecture is not only an important type of Western religious architecture in the Far East, but also an important witness of cultural exchanges between China and the West. It is gradually being paid attention to by international and modern Chinese architecture researchers.

However, due to the lack of documentation and the non-extensive nature of Christian missionary groups in China, modern Chinese Christian church architecture is in urgent need of research and conservation. Relevant studies are mostly on single or region-specific church architecture, such as "The Religious Architecture of Macau" (Liu Xianjue, 2002) $)^{1}$, "Modern Church Architecture in Lingnan" (Dong Li, 2005) ${ }^{2}$, etc. There is very little review of the overall specific styles of churches in Mainland China, Macau and Hong Kong, such as "Neoclassicism in China and the West" (Gotina, 2005)3. "A Study of Modern Chinese Christian Church Architecture" (Xu Min, 2010) ${ }^{4}$ compares the evolution of the architectural styles of Christian churches in modern China, but does not further explore the differences between the styles of churches in the mainland, Macau and Hong Kong. Judging from the data collected so far, based on the research of single church architecture, there is no research to comprehensively sort out the architectural styles of Christian churches in the three regions and further analyze the differences between them.

\section{Research purpose and Method}

Based on the architectural research of individual churches, this article comprehensively summarizes the styles of Christian churches in mainland China, Macau and Hong Kong, and further systematically explores the differences in the styles of Christian churches in the three regions.

The research method is divided into three steps: First, use the method of literature investigation and field research to collect representative church examples that have been preserved and have historical value during the spread of Christianity in modern China. Then apply statistical methods to investigate and compare the existing architectural styles of churches in Mainland China and Macau and Hong Kong. Finally, explore the reasons for the differences in church architectural styles.

\section{Statistics on the Styles of Modern Christian Churches in Mainland China, Macau and Hong Kong}

(1) Mainland China (Table 1): Christian churches in mainland China are mostly Gothic II (12 seats) and Eclectic (8 seats), with Gothic II as the main style, accounting for more than half. The remaining small parts are neoclassical (3 seats). Renaissance and Baroque styles

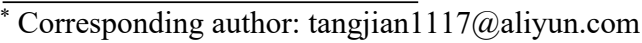


Table 1. Christian Churches in Mainland China (in order of construction)

\begin{tabular}{|c|c|c|c|c|}
\hline & Name & Year of construction & $\begin{array}{l}\text { Denomina } \\
\text {-tion }\end{array}$ & $\begin{array}{l}\text { Existing } \\
\text { architectural style }\end{array}$ \\
\hline 1 & $\begin{array}{l}\text { Cathedral of the Immaculate Conception, } \\
\text { Beijing }\end{array}$ & First built in 1605, rebuilt in 1902 & Catholicism & $\begin{array}{l}\text { Eclecticism (with } \\
\text { baroque elements) }\end{array}$ \\
\hline 2 & St. Joseph's Church, Beijing & First built in 1655, rebuilt in 1904 & Catholicism & Neoclassicism \\
\hline 3 & St. Francis Cathedral, Xi'an & $\begin{array}{l}\text { First built in 1716-1727, rebuilt in } \\
1765-1785\end{array}$ & Catholicism & Eclecticism \\
\hline 4 & St. Francis Xavier Church, Shanghai & Built in 1847 & Catholicism & $\begin{array}{l}\text { Eclecticism (with } \\
\text { baroque elements) }\end{array}$ \\
\hline 5 & Sacred Heart Cathedral, Guangzhou & Built in 1861 & Catholicism & Gothic II \\
\hline 6 & Shamian Christian Church, Guangzhou & Built in 1864 , renovated in 1931 & Christianity & Eclecticism \\
\hline 7 & Holy Trinity Cathedral, Shanghai & Built in 1866 & Christianity & Gothic II \\
\hline 8 & $\begin{array}{l}\text { Église Notre-Dame des Victoires } \\
\text { (French), Tianjin }\end{array}$ & First built in 1869, rebuilt in 1903 & Catholicism & Gothic II \\
\hline 9 & Asbury Church, Beijing & First built in 1870, rebuilt in 1909 & Christianity & Eclecticism \\
\hline 10 & Sheshan Basilica, Shanghai & First built in 1871, rebuilt in 1925 & Catholicism & Gothic II \\
\hline 11 & $\begin{array}{l}\text { Sacred Heart of Jesus Cathedral, } \\
\text { Shenyang }\end{array}$ & First built in 1876, rebuilt in 1912 & Catholicism & Gothic II \\
\hline 12 & East Soochow Methodist Church, Suzhou & First built in 1881, rebuilt in 1915 & Christianity & Eclecticism \\
\hline 13 & Church of the Saviour, Beijing & Built in 1888 , renovated in 1985 & Catholicism & Gothic II \\
\hline 14 & $\begin{array}{l}\text { Our Lady of Lourdes Chapel, Shamian } \\
\text { Island, Guangzhou }\end{array}$ & Built in 1889 & Catholicism & Gothic II \\
\hline 15 & Sacred Heart Cathedral, Jinan & Built in 1901 & Catholicism & Gothic II \\
\hline 16 & St. Victor Cathedral, Zhanjiang & Built in 1902 & Catholicism & Gothic II \\
\hline 17 & Sanyi International Church, Kunming & First built in 1903, rebuilt in 2003 & Christianity & Gothic II \\
\hline 18 & St. Ignatius Cathedral, Shanghai & Built in 1906 & Catholicism & Gothic II \\
\hline 19 & St. Joseph Cathedral, Tianjin & Built in 1916, renovated in 1979 & Catholicism & Neoclassicism \\
\hline 20 & Community Church, Shanghai & Built in 1923 & Christianity & Eclecticism \\
\hline 21 & St. Michael's Cathedral, Qingdao & Built in 1932 & Catholicism & Gothic II \\
\hline 22 & Mochou Road Church, Nanjing & Built in 1936 & Christianity & Eclecticism \\
\hline 23 & St. Paul's Church, Qingdao & Built in 1938 & Christianity & Neoclassicism \\
\hline
\end{tabular}

Table 2. Christian Churches in Macau (in order of construction)

\begin{tabular}{|c|l|l|l|l|}
\hline & \multicolumn{1}{|c|}{ Name } & \multicolumn{1}{|c|}{ Year of construction } & \multicolumn{1}{|c|}{$\begin{array}{c}\text { Denomina } \\
\text {-tion }\end{array}$} & $\begin{array}{c}\text { Existing } \\
\text { architectural styles }\end{array}$ \\
\hline 1 & St. Lazarus' Church, Macau & First built in 1557, rebuilt in 1896 & Catholicism & $\begin{array}{l}\text { Eclecticism } \\
\text { (Baroque and } \\
\text { neoclassical mix) }\end{array}$ \\
\hline 2 & St. Lawrence's Church, Macau & First built in 1558, renovated in 1844 & Catholicism & $\begin{array}{l}\text { Eclecticism } \\
\text { (Gothic II and } \\
\text { Baroque mix) }\end{array}$ \\
\hline 3 & $\begin{array}{l}\text { Igreja de Santo António (Portuguese), } \\
\text { Macau }\end{array}$ & $\begin{array}{l}\text { First built in 1558-1560, rebuilt in } \\
1930\end{array}$ & Catholicism & Neoclassicism \\
\hline 4 & $\begin{array}{l}\text { Igreja de Santo Agostinho (Portuguese), } \\
\text { Macau }\end{array}$ & First built in 1587, rebuilt in 1874 & Catholicism & Neoclassicism \\
\hline 5 & St. Dominic's Church, Macau & $\begin{array}{l}\text { First built in 1588, rebuilt in 1721 } \\
\text { and 1828 }\end{array}$ & Catholicism & Baroque \\
\hline 6 & Ruins of Saint Paul's, Macau & $\begin{array}{l}\text { First built in 1602, then rebuilt } \\
\text { several times }\end{array}$ & Catholicism & Baroque \\
\hline 7 & $\begin{array}{l}\text { Capela de Nossa Senhora da Guia } \\
\text { (Portuguese), Macau }\end{array}$ & $\begin{array}{l}\text { First built before 1622, rebuilt in } \\
1864 .\end{array}$ & Catholicism & Renaissance \\
\hline 8 & Our Lady of Penha Chapel, Macau & $\begin{array}{l}\text { First built in 1622, rebuilt in 1837 } \\
\text { and 1935 }\end{array}$ & Catholicism & Neoclassicism \\
\hline 9 & $\begin{array}{l}\text { Cathedral of the Nativity of Our Lady, } \\
\text { Macau }\end{array}$ & $\begin{array}{l}\text { First built in 1622, rebuilt in 1849 } \\
\text { and 1937. }\end{array}$ & Catholicism & Neoclassicism \\
\hline 10 & St. Joseph's Seminary and Church, Macau & Built in 1728 & Catholicism & Baroque \\
\hline 11 & Protestant Chapel, Macau & First built in 1821, rebuilt in 1921 & Christianity & Neoclassicism \\
\hline 12 & St. Michael, the Archangel, Macau & $\begin{array}{l}\text { First built in 1873, then rebuilt many } \\
\text { times }\end{array}$ & Catholicism & Gothic II \\
\hline 13 & Our Lady of Carmel Church, Macau & First built in 1885, renovated in 1985 & Catholicism & Neoclassicism \\
\hline
\end{tabular}


Table 3. Christian Churches in Hong Kong (in order of construction)

\begin{tabular}{|c|l|l|l|l|}
\hline & \multicolumn{1}{|c|}{ Name } & \multicolumn{1}{|c|}{ Year of construction } & \multicolumn{1}{|c|}{$\begin{array}{c}\text { Denomina } \\
\text {-tion }\end{array}$} & \multicolumn{1}{|c|}{$\begin{array}{c}\text { Existing } \\
\text { architectural } \\
\text { styles }\end{array}$} \\
\hline 1 & $\begin{array}{l}\text { Cathedral of the Immaculate } \\
\text { Conception, Hong Kong }\end{array}$ & First built in 1842, rebuilt in 1888 & Catholicism & Gothic II \\
\hline 2 & St John's Cathedral, Hong Kong & $\begin{array}{l}\text { First built in 1847, renovated in } \\
1865\end{array}$ & Christianity & Gothic II \\
\hline 3 & Béthanie, Hong Kong & $\begin{array}{l}\text { First built in 1875, then } \\
\text { remodeled several times }\end{array}$ & Catholicism & Gothic II \\
\hline 4 & Rosary Church, Hong Kong & $\begin{array}{l}\text { First built in 1901, renovated in } \\
1990\end{array}$ & Catholicism & Neoclassicism \\
\hline 5 & Chinese Rhenish Church, Hong Kong & First built in 1914 & Christianity & Neoclassicism \\
\hline 6 & Shing Kwong Church, Hong Kong & First built in 1890, rebuilt in 1926 & Christianity & Neoclassicism \\
\hline 7 & St. Margaret's Church, Hong Kong & Built in 1923 & Catholicism & Neoclassicism \\
\hline 8 & $\begin{array}{l}\text { The Church of Christ in China Hop } \\
\text { Yat Church, Hong Kong }\end{array}$ & Built in 1924 & Christianity & Gothic II \\
\hline 9 & $\begin{array}{l}\text { Tsung Tsin Mission of Hong Kong } \\
\text { Kau Yan Church, Hong Kong }\end{array}$ & First built in 1852, rebuilt in 1931 & Christianity & Neoclassicism \\
\hline
\end{tabular}

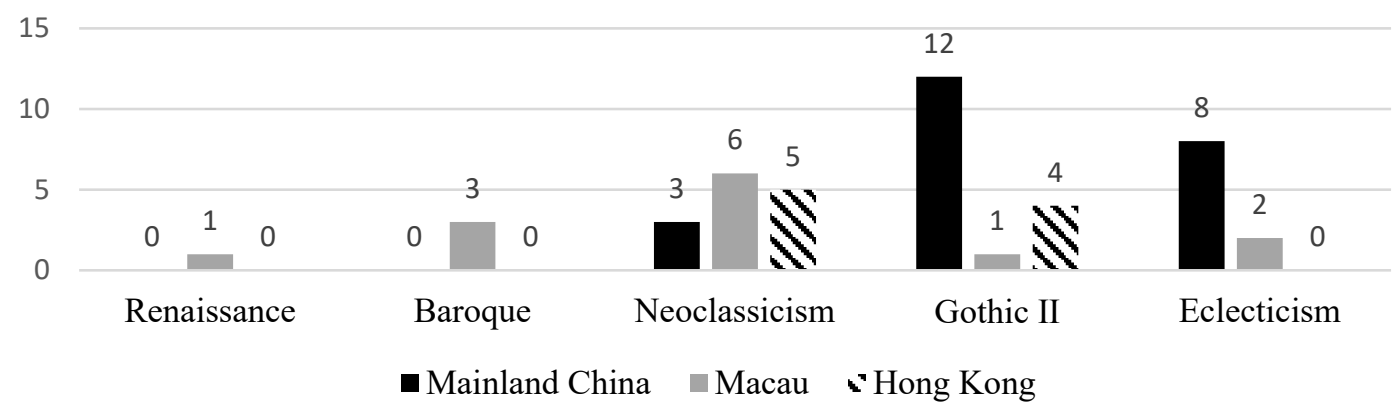

Figure 1. Statistics on the styles of Christian churches in Mainland China, Macau and Hong Kong

are not seen in the existing churches. (Although Cathedral of the Immaculate Conception in Beijing and St. Francis Xavier Church in Shanghai have Baroque elements, the existing architectural styles are eclectic.)

(2) Macau (Table 2): The existing Christian churches in Macau are mainly Baroque (3 seats) and Neoclassical (6 seats), and it is the only region in China where Renaissance and Baroque churches are extant. Most of the extant churches are Neoclassical, with very few Gothic II churches (1 seat).

(3) Hong Kong (Table 3): Christian churches in Hong Kong are Neoclassical (5 seats) and Gothic II (4 seats).

\section{Data Analysis}

Based on the results of the above data, there are significant differences in the architectural styles of modern Christian churches in Mainland China, Macau and Hong Kong.

(1) In the third Christian (Catholic) mission, Macau was earlier than Mainland China and Hong Kong and was the "City of the Holy name of God". Therefore, there were Baroque churches that were prevalent in the West earlier in the history. There were even Renaissance churches in the 17th century that has been preserved to this day.

From 1557 to 1562 , barbarian merchants landed in and settled buildings in Macau. Before Matteo Ricci came to China, this place had always been the only stronghold of the Jesuit mission in China, and it is also the main base and channel for Catholicism to infiltrate China. At the same time, Europe had gone through the Renaissance to the late Baroque, and capitalism had emerged. The architectural styles of Macau churches were affected by this, and most of them adopted the Baroque style prevailing in the West at that time or even the earlier Renaissance style, which have been preserved to this day.

After the Opium War in 1840, with the help of a series of unequal treaties, churches of various denominations began to build churches in mainland China and Hong Kong on a large scale. At this time, neoclassicism and Gothic II were prevalent in the West, and then eclecticism appeared. What is interesting was that most churches built in mainland China adopted the Gothic II style, while the churches built in Hong Kong mostly adopted the Neoclassical style, followed by the Gothic II.

(2) Macau is the "City of the Holy name of God" and a colony, and Hong Kong is also a colony. However, the mainland of China is a semi-colonial place where the so-called "pagans" are located, and the more Gothic II style churches are notable features.

Portugal had landed and settled in Macau as early as 
1557, and Hong Kong was occupied by the British in 1841. Hong Kong and Macau had become leaseholds of Western powers. In Western culture, although Baroque architecture is vigorous, it is still a horizontal composition. Neoclassical architecture emphasizes the unique order and human dignity more. In Macau and Hong Kong, more baroque and neoclassical church buildings were built to demonstrate the humanity of Christianity and attract more believers with gentleness.

In the vertical system of Gothic and Gothic II church buildings, the towering towers and pointed arches are metaphors for the ascension to God. The murals and statues inside the building, together with the exterior image of the building, create a pious and mysterious religious atmosphere. Therefore, compared with other styles of architecture, Gothic or Gothic II church mission is a clearer display of "theocracy" rather than "human rights". After the Opium War, mainland China was still semi-colonial, and people were still fighting against imperialism. The spread of Christianity was not progressing smoothly. It can be seen from Table 1 that there are obviously more Gothic II churches in the interior than other styles, which better fit the missionary purpose of highlighting the sacredness and sublime of Christianity and allowing devout believers to perceive the majestic existence of God.

\section{Conclusion}

The existing Christian churches in Mainland China are mainly in the Gothic II style; the existing Christian churches in Macau are mostly Baroque and neoclassical styles; the Hong Kong Christian churches are in neoclassical and Gothic II styles. The main reasons for the differences in church styles between the Mainland China, Macau and Hong Kong are as follows:

(1) In the third Christian (Catholic) mission, Macau was earlier than Mainland China and Hong Kong and was the "City of the Holy name of God". Therefore, there were Baroque churches that were prevalent in the West earlier in the history. There were even Renaissance churches in the 17 th century that has been preserved to this day. In Western culture, although Baroque architecture is vigorous, it is still a horizontal composition. Neoclassical architecture emphasizes the unique order and human dignity more. Especially, neoclassicism is associated with the "human rights" of the emerging bourgeoisie.

(2) There are significantly more vertical Gothic II churches in mainland China than in Macau and Hong Kong. The missionaries chose a different missionary approach. A large number of Gothic II churches built in mainland China better fit the missionary purpose of highlighting the sacredness and sublime of Christianity and allowing devout believers to perceive the majestic existence of God.

It is true that Christian churches of various styles invaded China along with the imperialist ships and guns, but they gradually incorporated the connotation of Chinese traditional culture, completing the infusion and interpretation of the local architectural language in the Chinese background. This stone-made "historical book" has left a brilliant stroke in the history of Chinese architecture and is worthy of further in-depth research.

\section{Acknowledgments}

This work is funded by the open fund of the Guangdong Engineering Technology Research Center for Green Building Materials and Fabricated Architecture (No. ZCZX201801) and National Social Science Fund of China (Grants No.20BZJ026).

\section{References}

1.Liu, X.J., Xu, Z. (2002) Religious Architecture in Macau [J]. Huazhong Architecture, 2002 (6): 84-91.

2.Dong, L. (2005) Modern church buildings in Lingnan [M]. China Construction Industry Press, Beijing.

3.Ge, T. (2005) Neoclassicism in China and the West[J]. Huazhong Architecture, 2005 (5): pp26-28.

4.Xu, M. (2010) A Study of Modern Chinese Christian Church Architecture[D]. Nanjing University of the Arts.

5.Zheng, H. (2015) A preliminary exploration of the spread of Gothic architectural style in China in the late Qing and early Ming dynasties[J]. Beauty and the Times (above), 2015 (12): 66-68.

6.Liu, N. (2014) Research on the Place Spirit of the Gothic Church in the Middle Ages [D]. Xi'an University of Architecture and Technology.

7.Sun, S.Y. (2017) A brief discussion on the spread and development of Christian culture in China [J]. Journal of the Central Institute of Socialism, 2017(04): 104-112.

8.Zhang, F.H. (1988) A Preliminary Study of Chinese Christian Church Architecture[J]. Huazhong Architecture, 1988(03): 10-17. 